\title{
Prophetic Medicine-Nigella Sativa (Black Cumin Seeds) - Potential Herb for COVID-19?
}

\author{
Naina Mohamed Pakkir Maideen ${ }^{1 *}$
}

1Dubai Health Authority, Dubai, United Arab Emirates

\section{Key Words}

Nigella sativa, black seeds, antiviral, antioxidant, anti-inflammatory, anticoagulant

\begin{abstract}
Coronavirus disease-19 (COVID-19) is caused by the severe acute respiratory syndrome coronavirus 2 (SARS CoV-2). Currently, the management of patients with COVID-19 depends mainly on repurposed drugs which include chloroquine, hydroxychloroquine, lopinavir/ ritonavir, ribavirin, remdesivir, favipiravir, umifenovir, interferon- $\alpha$, interferon- $\beta$ and others. In this review, the potential of Nigella sativa (black cumin seeds) to treat the patients with COVID-19 analyzed, as it has shown to possess antiviral, antioxidant, anti-inflammatory, anticoagulant, immunomodulatory, bronchodilatory, antihistaminic, antitussive, antipyretic and analgesic activities. Medline/PubMed Central/PubMed, Google Scholar, Science Direct, Directory of open access journals (DOAJ) and reference lists were searched to identify articles associated with antiviral and other properties of N.sativa related to the signs and symptoms of COVID-19. Various randomized controlled trials, pilot studies, case reports and in vitro and in vivo studies confirmed that N.sativa has antiviral, antioxidant, anti-inflammatory, immunomodulatory, bronchodilatory, antihistaminic, antitussive activities related to causative oraganism and signs and symptoms of COVID-19. $N$. sativa could be used as an adjuvant therapy along with repurposed conventional drugs to manage the patients with COVID-19.
\end{abstract}

Received: May 30, 2020 Reviewed: Jun 02, 2020 Accepted: Jun 08, 2020

\section{Introduction}

Coronavirus disease-19 (COVID-19) is caused by the severe acute respiratory syndrome coronavirus 2 (SARS CoV-2) and this virus was first originated from Wuhan city of Hubei province of China spreading around the globe [1]. Around 5 million of COVID-19 cases have been reported across the world and 0.3 million deaths occurred among them, till 21st May 2020 [2].

The prominent symptoms of COVID-19 include fever, cough and dyspnea [3] and other symptoms noted in patients affected by COVID-19 may include chills, repeated shaking with chills, muscle pain, headache, sore throat and new loss of taste or smell [4]. In addition, the emergency warning signs of COVID-19 include difficulty breathing or shortness of breath, persistent pain or pressure in the chest, new confusion or inability to arouse and bluish lips or face and the patients experiencing any of these signs should get immediate medical attention [5].

The development of specific antiviral drugs and vaccines to treat COVID-19 patients will take months or years to complete. Hence, the treatments of COVID-19 depend mainly on repurposed drugs which include chloroquine, hydroxychloroquine, lopinavir/ritonavir, ribavirin, remdesivir, favipiravir, umifenovir, interferon- $\alpha$, interferon- $\beta$ and others. As of this time, there is no specific, effective and proven conventional medicine to manage patients affected by COVID-19 and as of April 2, 2020, there are 291 active clinical trials found specific to COVID-19. Among them 109 trials included pharmacological therapy for the treatment of COVID-19 in adult patients [6].
(C) This is an Open-Access article distributed under the terms of the Creative Commons Attribution Non-Commercial License (http://creativecommons.org/licenses/by-nc/4.0/) which permits unrestricted noncommercial use, distribution, and reproduction in any medium, provided the original work is properly cited.

$\otimes$ This paper meets the requirements of KS X ISO 9706, ISO 9706-1994 and ANSI/NISO Z39.48-1992 (Permanence of Paper).
Corresponding Author

Naina Mohamed Pakkir Maideen. Pharmacologist, Dubai Health Authority 4545, Dubai, United Arab Emirates.

Tel: +971-4216-4952, +971-5057-69833 Fax: +971-4224-4302

E-mail:nmmaideen@dha.gov.ae 
Similarly, the herbal medicine can contribute as an alternative measure to manage the patients with COVID-19 as there are many traditional herbs shown antiviral and other medicinal properties.

In this review, the potential of Nigella sativa (black cumin seeds) to treat the patients with COVID-19 analyzed, as Prophet Muhammad (PBUH) stated that "In the black cumin, there is a cure for every disease except death". In addition, the black cumin is also mentioned in Holy Bible as "Curative black seed" and is described as "Melanthion of Hippocrates and Dioscorides' and as 'Glitch of Pliny' [7].

$N$. sativa belongs to the Ranunculacea family and it is also known as black cumin seed, black seed, Habbatul Barakah, Habbatus sawda, kalonji, etc [8]. In traditional medicine, $N$. sativa has been used for centuries to treat various illnesses including asthma, common cold, headache, nasal congestion, rheumatic diseases, warts and many others [9]. More recently, $N$. sativa has been used to treat conditions like infections, cancer, diabetes, hypertension, obesity, cardiovascular diseases, and gastrointestinal problems [10]. The medicinal properties of $N$. sativa have been demonstrated in Unani, Chinese medicine, ayurveda and other medicinal systems [11].

Phytochemical screening of N.Sativa revealed that it contains various compounds including terpenes, flavanoids, phytosterols, tannins, coumarins, phenolic compounds, alkaloids, cardiac glycosides, saponins, fatty acids, and volatile oils. The bioactive constituents of $N$. sativa include terpenes such as thymoquinone (TQ), dithymoquinone (DTQ), carvone, limonine, trans-anethol, and p-cymene, indazole alkaloids like nigellidine and nigellicine, and

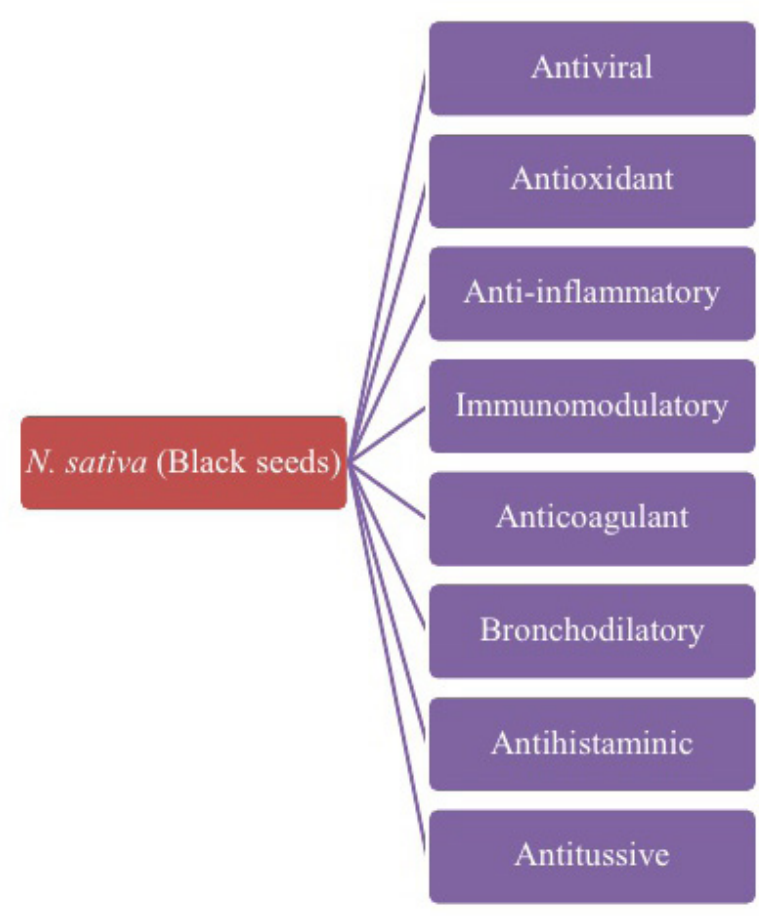

Figure 1 Drugs used for arthritis. Conventional Disease Modifying Anti-Rheumatic Drugs (DMARDs) isoquinoline alkaloids including nigellicimine, nigellicimine-N-oxide and $\alpha$-hederin [12].

As N.sativa possesses antiviral, antioxidant, anti-inflammatory, anticoagulant, immunomodulatory, bronchodilatory, antihistaminic, antitussive, antipyretic and analgesic activities (Fig. 1), it would be a potential herbal candidate to treat the patients with COVID-19 (Table 1). In addition, N.sativa has also shown anti-hypertensive, anti-obesity, anti-diabetic, anti-hyperlipidemic, anti-ulcer, and antineoplastic activities which would help the COVID-19 patients with comorbid conditions [13]. Moreover, the active constituents of N.sativa including nigellidine and $\alpha$-hederin have been identified as potential inhibitors of SARS CoV-2 [14].

\section{Methods}

Medline/PubMed Central/PubMed, Google Scholar, Science Direct, Directory of open access journals (DOAJ) and reference lists were searched to identify articles associated with antiviral and other properties of N.sativa related to the signs and symptoms of COVID-19 using keywords such as Nigella sativa, black cumin, black seeds, antiviral, antioxidant, anti-inflammatory, immunomodulatory, bronchodilatory, antihistaminic, antitussive and COVID-19. All the studies assessing the antiviral effects and other medicinal properties related to the signs and symptoms of COVID-19 of N.sativa were included in this review.

\section{Results}

\subsection{Antiviral activity}

Many clinical studies have proven that $N$. sativa is very much effective in treating patients infected with viruses such as Human Immunodeficiency Virus (HIV) as well as Hepatitis C Virus (HCV).

A study recruited 51 HIV-positive patients and they were administered with $\alpha$-Zam (herbal concoction containing $N$. sativa and honey) for 16 months. All the patients were relieved of all the signs and symptoms of HIV infection within 4 weeks of commencement of $\alpha$-Zam therapy. At the end of the herbal therapy, undetectable viral load has been noted in 41 patients and less than 1000 copies $/ \mathrm{ml}$ of viral load in 10 patients. In addition to decreased viral load, the CD4 count of all participants has been increased [15]. Another study included six HIV-positive patients who took a-Zam (herbal concoction containing $N$. sativa and honey for 4 months and their signs and symptoms of HIV infection disappeared in 20 days of $\alpha$-Zam treatment. Moreover, at the end of 4 months, the viral load (HIV-RNA) of the patients decreased consistently to an undetectable level along with increased body weight and CD4 count [16].

Moreover, a complete seroreversion was evidently reported in a 46-year-old HIV positive patient who took $10 \mathrm{ml}$ of N.sativa concoction ( $60 \%$ of N.sativa seeds and $40 \%$ of honey) two times daily for 6 months. Repeated HIV tests of the patient have shown sustained seroreversion (un- 
Table 2 Drugs used for arthritis. Conventional Disease Modifying Anti-Rheumatic Drugs (DMARDs)

\begin{tabular}{|c|c|c|c|c|}
\hline S.No & $\begin{array}{c}\text { Pharmacological } \\
\text { Activity }\end{array}$ & Type of Study & $\begin{array}{c}\text { No. of } \\
\text { Participants }\end{array}$ & Findings \\
\hline 1 & $\begin{array}{l}\text { Antiviral } \\
\text { (Anti-HIV) }\end{array}$ & Pilot study [15] & 51 & $\begin{array}{l}\text { Undetectable viral load noted in } 41 \\
\text { patients and less than } 1000 \text { copies } / \mathrm{ml} \\
\text { of viral load in } 10 \text { patients. } \\
\text { CD4 count of all participants has } \\
\text { been increased. }\end{array}$ \\
\hline 2 & $\begin{array}{l}\text { Antiviral } \\
\text { (Anti-HIV) }\end{array}$ & Pilot study [16] & 6 & $\begin{array}{l}\text { Undetectable viral load (HIV-RNA) } \\
\text { in all patients. } \\
\\
\text { Increased body weight } \\
\text { Increased CD4 count. }\end{array}$ \\
\hline 3 & $\begin{array}{l}\text { Antiviral } \\
\text { (Anti-HIV) }\end{array}$ & Case report [17] & 1 & $\begin{array}{l}\text { Complete seroreversion. } \\
\text { Normal CD4 count. }\end{array}$ \\
\hline 4 & $\begin{array}{l}\text { Antiviral } \\
\text { (Anti-HIV) }\end{array}$ & Case report [18] & 1 & $\begin{array}{l}\text { Sustained seroreversion. } \\
\text { CD4 count not less than } 750 \text { cells } / \mu \mathrm{L} \text {. }\end{array}$ \\
\hline 5 & $\begin{array}{l}\text { Antiviral } \\
\text { (Anti-HCV) }\end{array}$ & Pilot study [19] & 30 & $\begin{array}{l}\text { Significant decrease in viral load. } \\
\text { Increased Total Antioxidant Capacity } \\
\text { (TCA). } \\
\text { Improved laboratory biomarkers such } \\
\text { as total protein, red blood cell, and } \\
\text { platelet count. } \\
\text { Decreased fasting blood glucose and } \\
\text { postprandial glucose in both diabetic } \\
\text { and non-diabetic HCV patients. } \\
\text { Reduced lower-limb edema }\end{array}$ \\
\hline 6 & $\begin{array}{l}\text { Antiviral } \\
\text { (Anti-HCV) }\end{array}$ & Pilot study [20] & 60 & $\begin{array}{l}\text { Significant decrease in viral load. } \\
\text { Augmentation of } \alpha \text {-fetoprotein and } \\
\text { other liver function parameters. }\end{array}$ \\
\hline 7 & $\begin{array}{c}\text { Antiviral } \\
\text { (Anti-HCV) }\end{array}$ & Pilot study [21] & 195 & Negative HCV-RNA \\
\hline 8 & Antioxidant & $\begin{array}{c}\text { Randomized } \\
\text { controlled } \\
\text { clinical trial [30] }\end{array}$ & 50 & $\begin{array}{l}\text { Significant raise of levels of } \\
\text { superoxide dismutase (SOD). }\end{array}$ \\
\hline 9 & Antioxidant & $\begin{array}{c}\text { Placebo } \\
\text { controlled } \\
\text { participant } \\
\text { blinded clinical } \\
\text { trial [31] } \\
\end{array}$ & 114 & $\begin{array}{c}\text { Significant elevation of total } \\
\text { antioxidant capacity (TAC), } \\
\text { superoxide dismutase (SOD), and } \\
\text { glutathione levels. }\end{array}$ \\
\hline 10 & Antioxidant & Pilot study [32] & 30 & $\begin{array}{l}\text { Significant reduction of plasma levels } \\
\text { of malondialdehyde (MDA). } \\
\text { Increased activity of erythrocyte } \\
\text { glutathione peroxidase (GSH-Px) and } \\
\text { superoxide dismutase. }\end{array}$ \\
\hline 11 & Anti-inflammatory & $\begin{array}{c}\text { Placebo } \\
\text { controlled study } \\
{[39]} \\
\end{array}$ & 40 & $\begin{array}{l}\text { Improvement in number of inflamed } \\
\text { joints, incidence of morning stiffness, } \\
\text { and disease activity score. }\end{array}$ \\
\hline
\end{tabular}




\begin{tabular}{|c|c|c|c|c|}
\hline 12 & Anti-inflammatory & $\begin{array}{l}\text { Randomized, } \\
\text { double blind, } \\
\text { placebo- } \\
\text { controlled } \\
\text { clinical trial [40] }\end{array}$ & 42 & $\begin{array}{l}\text { Significant decrease in the levels of } \\
\text { malondialdehyde (MDA) and nitric } \\
\text { oxide (NO). }\end{array}$ \\
\hline 13 & Anti-inflammatory & $\begin{array}{l}\text { Randomized } \\
\text { double blind, } \\
\text { placebo- } \\
\text { controlled } \\
\text { clinical trial [41] }\end{array}$ & 90 & $\begin{array}{c}\text { Significant reduction of systemic } \\
\text { inflammatory biomarkers including } \\
\text { Tumor necrosis factor- } \alpha \text { (TNF- } \alpha \text { ) and } \\
\text { C-reactive protein (CRP). }\end{array}$ \\
\hline 14 & Anti-inflammatory & $\begin{array}{l}\text { Randomized } \\
\text { double blind, } \\
\text { placebo- } \\
\text { controlled } \\
\text { clinical trial [42] }\end{array}$ & 43 & $\begin{array}{c}\text { Significant reduction of serum levels } \\
\text { of malondialdehyde (MDA) and } \\
\text { nitric oxide (NO). }\end{array}$ \\
\hline 15 & Anti-inflammatory & $\begin{array}{c}\text { Randomized } \\
\text { double blind, } \\
\text { placebo- } \\
\text { controlled } \\
\text { clinical trial [43] }\end{array}$ & 96 & $\begin{array}{l}\text { Significant reduction of serum levels } \\
\text { of malondialdehyde (MDA). }\end{array}$ \\
\hline 16 & Immunomodulatory & Pilot study [47] & 24 & $\begin{array}{l}\text { Significant raise of CD8 counts and } \\
\text { polymorphonuclear leukocyte } \\
\text { (PMN). } \\
\text { Improved clinical symptoms. }\end{array}$ \\
\hline 17 & Immunomodulatory & $\begin{array}{c}\text { Randomized } \\
\text { double blind, } \\
\text { placebo- } \\
\text { controlled } \\
\text { clinical trial [48] }\end{array}$ & 43 & $\begin{array}{l}\text { Decreased } \mathrm{CD} 8^{+} \text {and increased } \\
\text { percentage of } \mathrm{CD} 4^{+} \mathrm{CD} 25^{+} \text {and the } \\
\text { ratio of } \mathrm{CD} 4^{+} / \mathrm{CD} 8^{+} \text {. }\end{array}$ \\
\hline 18 & Anticoagulant & $\begin{array}{c}\text { Randomized } \\
\text { double blind, } \\
\text { placebo- } \\
\text { controlled } \\
\text { clinical trial [51] }\end{array}$ & 94 & $\begin{array}{l}\text { Significant increase in Partial } \\
\text { thromboplastin time (PTT). } \\
\text { Significant reduction of systolic } \\
\text { blood pressure, diastolic blood } \\
\text { pressure, means arterial pressure, and } \\
\text { heart rate. }\end{array}$ \\
\hline 19 & Bronchodilatory & $\begin{array}{c}\text { Randomized } \\
\text { double blind } \\
\text { clinical trial [54] }\end{array}$ & 15 & $\begin{array}{l}\text { Short significant increase in peak } \\
\text { expiratory flow (PEF), forced } \\
\text { expiratory volume in one second } \\
\left(F^{\prime} V_{1}\right) \text {, maximal expiratory flow } \\
\text { (MEF), maximal mid expiratory flow } \\
\text { (MMEF), and specific airway } \\
\text { conductance. }\end{array}$ \\
\hline 20 & Bronchodilatory & $\begin{array}{l}\text { Randomized } \\
\text { single-blind } \\
\text { placebo- } \\
\text { controlled } \\
\text { clinical trial [55] }\end{array}$ & 73 & $\begin{array}{l}\text { Significant improvements in forced } \\
\text { expiratory volume in one second } \\
\left(\mathrm{FEV}_{1}\right) \text {, peak expiratory flow (PEF), } \\
\text { serum interferon- } \gamma \text {, and asthma } \\
\text { control test (ACT) score. } \\
\text { Significant reduction of fractional } \\
\text { exhaled nitric oxide (FeNO) and } \\
\text { serum total immunoglobulin E (IgE). }\end{array}$ \\
\hline 21 & Antihistaminic & $\begin{array}{c}\text { Randomized } \\
\text { single-blind } \\
\text { clinical trial [56] }\end{array}$ & 20 & $\begin{array}{l}\text { Significant reduction of seasonal } \\
\text { allergic rhinitis symptoms score. }\end{array}$ \\
\hline 22 & Antihistaminic & $\begin{array}{l}\text { Randomized } \\
\text { single-blind } \\
\text { uncontrolled } \\
\text { comparative } \\
\text { clinical trial [57] }\end{array}$ & 47 & $\begin{array}{c}\text { Significant reduction of daytime and } \\
\text { ophthalmic symptoms and total } \\
\text { eosinophil count comparable to } \\
\text { montelukast. }\end{array}$ \\
\hline 23 & Antihistaminic & $\begin{array}{c}\text { Randomized } \\
\text { double blind } \\
\text { clinical trial [58] }\end{array}$ & 66 & $\begin{array}{l}\text { Reduction of clinical symptoms such } \\
\text { as nasal itching, rhinorrhea, sneezing } \\
\text { attacks, nasal congestion, turbinate } \\
\text { hypertrophy and mucosal pallor. }\end{array}$ \\
\hline 24 & Antihistaminic & Pilot study [59] & 68 & $\begin{array}{c}\text { Relief of symptoms of allergic } \\
\text { rhinitis. }\end{array}$ \\
\hline
\end{tabular}


detectable viral (HIV-RNA) load) and normal CD4 count since 24 months without N.sativa therapy [17]. Similarly, a sustained seroreversion was noted in a 27 -year-old HIV infected pregnant woman who was not eligible for antiretroviral therapy, received $10 \mathrm{ml}$ of N.sativa and honey mixture ( $60 \%$ of N.sativa seeds and $40 \%$ of honey) three times daily for a year. Repeated serology assessments for 10 years have shown undetectable viral load and CD4 count not less than 750 cells/ $\mu \mathrm{L}[18]$.

The administration of soft gelatin capsules of $N$. sativa seed oil (450 mg) three times daily for 3 months to patients with Hepatitis C Virus (HCV) who were not eligible for Interferon- $\alpha$ therapy, resulted in significant decrease in viral load, increased Total Antioxidant Capacity (TCA) and improved laboratory biomarkers such as total protein, red blood cell, and platelet count, decreased fasting blood glucose, and postprandial glucose in both diabetic and non-diabetic HCV patients and reduced lower-limb edema [19] while, the administration of ethanolic extract of $N$. sativa in HCV patients found to decrease viral load significantly, to augment $\alpha$-fetoprotein and other liver function parameters and to overall clinical condition [20] and the administration of combination of natural products (N.sativa, honey, Blue green ${ }^{\bullet}$ tablet, vitamin D3, and linolenic acid) along with chloroquine in $195 \mathrm{HCV}$ patients who were not eligible for Interferon- $\alpha$ therapy, lead to negative HCV-RNA in 6 months among $42.1 \%$ of study participants and in 12 months among $54.9 \%$ of participants and $64.3 \%$ of participants achieved end of treatment response in 18 months [21].

The in vitro and in vivo studies of N.sativa has also shown antiviral efficacy against some other viruses like Murine cytomegalovirus (MCMV) [22], Papaya Ring Spot Virus [23], Hepatitis C Virus (HCV) [24], Avian influenza (H9N2) [25], Newcastle disease virus (NDV) [26] and Peste des Petits Ruminants (PPR) Virus [27]. It has been proposed that antiviral efficacy of N.sativa might be due to raised serum levels of interferon-gamma, increased CD4 count, augmented suppressor function and enhanced numbers of macrophages [22].

\subsection{Antioxidant activity}

The pathogenesis of SARS-CoV-2 infection is associated with overproduction of reactive oxygen species (ROS) and a deprived antioxidant system [28]. COVID-19 infection can induce the overproduction of numerous reactive oxygen species (ROS) like H2O2, (.O2-), (.OH), etc. through the stimulation of immunocytes such as macrophages and neutrophils. Multiple organ failure can occur due to excessive ROS which would oxidize cellular proteins and membrane lipids and destroy normal cells in lung and other organs including heart. Hence, potential antioxidants such as Vitamin C (ascorbic acid) and Vitamin E could be recommended to prevent organ damages [29]. $N$. sativa has shown some potential antioxidant properties in previous studies and its antioxidant activity may help to alleviate oxidative damages to the organs. A randomized controlled clinical trial of 50 obese volunteer women found that $N$. sativa oil significantly increased the levels of superoxide dismutase (SOD) which is important antioxidant enzyme acting against oxidative stress in the body [30].

In addition, a placebo controlled participant blinded clinical trial of 114 type 2 diabetic patients consisting equal number of participants in control group and N. sativa group, determined that the patients who received $2 \mathrm{gm}$ of $N$. sativa daily for 1 year have shown enhanced antioxidant defense system through significant elevation in total antioxidant capacity (TAC), superoxide dismutase (SOD), and glutathione levels [31]. Significant reduction of plasma levels of malondialdehyde (MDA) and increased activity of erythrocyte glutathione peroxidase (GSH-Px) and superoxide dismutase were reported in thirty postmenopausal women who took $N$. sativa seed and Allium sativum concomitantly for 2 months [32].

$N$. sativa has been reported for its effective antioxidant activities of in vivo and in vitro studies too. $N$. sativa oil has been shown to produce marked antioxidant activity in human pre-adipocytes [33], and the pre-treatment of human retinal pigment epithelial cells with thymoquinone of $N$. sativa protected them from hydrogen peroxide-induced oxidative stress through the activation of the nuclear factor erythroid 2-related factor 2 (Nrf2)/ Heme oxygenase-1 (HO-1) pathway [34]. And the bioactive constituents of $N$. sativa like thymoquinone, carvacrol, t-anethole and 4-terpineol demonstrated variable antioxidant activity [35].

\subsection{Anti-inflammatory activity}

Inflammation plays a crucial role in tissue damage occurring due to many chronic diseases like asthma, rheumatoid arthritis, cancer, diabetes, cardiovascular disorders, Alzheimer's disease, epilepsy and various infections [36]. The patients with severe COVID-19 observed with high levels of circulating inflammatory cytokines such as IL-6, IL-7 and tumor necrosis factor (TNF) and also of inflammatory chemokines including CC-chemokine ligand 2 (CCL2), CC-chemokine ligand 3 (CCL3) and CXC-chemokine ligand 10 (CXCL10). Disease severity and death are associated with excessive inflammatory response to SARS-CoV-2 infection [37]. The Janus kinase (JAK) inhibitor like Baricitinib is preferred as an anti-inflammatory agent to treat COVID-19 patients, as it has low plasma protein binding and has minimal interaction potential with CYP enzymes and drug transporters [38].

Previous studies have confirmed the anti-inflammatory activity of $N$. sativa which may reduce the effects of cytokine storm. A placebo controlled study of 40 female patients with rheumatoid arthritis (RA) who received $N$. sativa oil capsules $(500 \mathrm{mg}$ ) twice daily, has shown improvement in number of inflamed joints, incidence of morning stiffness, and disease activity score [39] and a randomized, double blind, placebo-controlled clinical trial of 42 patients with rheumatoid arthritis (RA) where the participants of intervention group received 2 capsules of $N$. sativa oil $500 \mathrm{mg}$, each day for 8 weeks and the levels of nitric oxide (NO) and malondialdehyde (MDA) decreased significantly in participants treated with N. sativa. The anti-inflammatory effect of $N$. sativa probably due to the inhibition of nuclear factor 
kappa B (NF-KB) [40].

Another randomized double blind, placebo-controlled clinical trial of 90 volunteer obese women who were divided equally in to intervention group (treated with the supplementation of $3 \mathrm{~g}$ of $N$. sativa oil daily) and a placebo group. The participants of both the groups were on low-calorie diet along with their supplementation for 8 weeks. The systemic inflammatory biomarkers including Tumor necrosis factor- $\alpha$ (TNF- $\alpha$ ) and C-reactive protein (CRP) were reduced in N. sativa treated group compared to placebo group [41]. The anti-inflammatory activity of $N$. sativa further revealed in another randomized double blind, placebo-controlled clinical trial of 43 patients with type 2 diabetes mellitus. Among them 23 patients were assigned to intervention group who were supplemented with $500 \mathrm{mg}$ of $N$. sativa capsules two times daily and 20 patients kept in placebo group, for 8 weeks. The serum levels of malondialdehyde (MDA) and nitric oxide (NO) decreased significantly in patients supplemented with $N$. sativa [42]. The anti-inflammatory activity of $N$. sativa further revealed in another randomized double blind, placebo-controlled clinical trial of 96 patients with Behcet's disease (BD) divided randomly as intervention group (received $1000 \mathrm{mg}$ /day of $N$. sativa oil capsules) and placebo group. The patients who received $N$. sativa showed significant reduction in the serum levels of malondialdehyde (MDA) and no significant changes were found in other parameters studied such as tumor necrosis factor- $\alpha$ (TNF- $\alpha$ ), Interleukin -10 (IL-10) and high sensitivity C-reactive protein (hs- CRP) probably due to lower dose of $N$. sativa [43]. Thymoquinone of $N$. sativa inhibited the formation of leukotrienes (LTC4 and LTB4) in human blood cells, probably due to the inhibition of 5-lipoxygenase and LTC4 synthase enzymes [44].

\subsection{Immunomodulatory effect}

Over activation of immune system could be found in hospitalized COVID-19 patients and it is described as a cytokine storm, which can lead to multiple organ failure. And it has been suggested that the need for ventilators and extracorporeal membrane oxygenation (ECMO) might be avoided by early and aggressive immunomodulatory treatment [45].

Certain active ingredients of $N$. sativa and its oil have shown beneficial immunomodulatory effects through the augmentation of immune responses related to $\mathrm{T}$ lymphocytes and natural killer cells [46]. A clinical study recruited 24 patients with allergic rhinitis sensitive to house dust mites and 7 healthy volunteers, administered with conventional doses of allergen-specific immunotherapy for 30 days. After a month of immunotherapy, 12 patients among 24 received the $2 \mathrm{~g}$ /day oral supplementation of $N$. sativa seed for 30 days that resulted in significant raise of CD8 counts and polymorphonuclear leukocyte (PMN) along with improved clinical symptoms [47] and a randomized, double-blinded placebo-controlled clinical trial of 43 female patients with mild to moderate rheumatoid arthritis (RA) revealed that administration of capsules of $500 \mathrm{mg} N$. sativa oil 2 times daily for 2 months resulted in modulation of T lymphocytes such as decreased CD8+ (suppressive lymphocyte), and increased percentage of
CD4+CD25+ and the ratio of CD4+/CD8+ [48].

\subsection{Anticoagulant activity}

Significant coagulopathy is attributed to severe COVID-19 infection [49] and to prevent venous thromboembolism, it is recommended to administer prophylactic dose of low molecular weight heparin (LMWH) in COVID-19 patients and the treatment dose of LMWH in patients with significantly higher d-dimer concentrations [50].

A clinical study of 94 patients (43 men and 51 women) with type 2 diabetes mellitus who were randomly divided into three groups receiving capsules containing $500 \mathrm{mg}$ of grounded $N$. sativa seeds in different doses of 1,2 , and $3 \mathrm{~g}$ of $N$. sativa daily for 12 weeks. The patients treated with 2 $\mathrm{g} /$ day of $N$. sativa seeds showed a significant increase in Partial thromboplastin time (PTT) along with a significant reduction in the systolic blood pressure, diastolic blood pressure, mean arterial pressure, and heart rate at the end of the study. Administration of NS seeds increased the PTT but not Prothrombin Time (PT) which indicates the inhibition of the intrinsic pathway of the clotting mechanism [51].

In vitro coagulation assays of thromboelastography (TEG) and activated partial thromboplastin time (aPTT) using pancreatic cancer cell lines, tested the anticoagulant effect of Thymoquinone of $N$. sativa and it has been determined that Thymoquinone reversed the cancer-associated thrombosis (CAT) by returning tissue factor (TF) and inflammation to basal levels. Moreover, Thymoquinone inhibited the activity of factor Xa significantly, at higher concentrations (0.8-1.6 mg/mL) [52].

Another set of in vitro coagulation assays of thrombin time (TT), prothrombin time (PT), and activated partial thromboplastin time (aPTT) testing the anticoagulant effect of $N$. sativa seed extract revealed that it has prolonged the coagulation time transiently. The prolongation of TT, PT and aPTT indicates that $N$. sativa inhibit the coagulation activity of extrinsic, common and intrinsic pathways probably due to the presence of coumarin like substance [53].

\subsection{Bronchodilatory effect}

A randomized double blind clinical trial of 15 patients with asthma who received 50 and $100 \mathrm{mg} / \mathrm{kg}$ of boiled extract of N. sativa seeds, showed a relatively potent bronchodilatory effect through a short significant increase in peak expiratory flow (PEF), forced expiratory volume in one second (FEV1), maximal expiratory flow (MEF), maximal mid expiratory flow (MMEF), and specific airway conductance [54].

Another randomized single-blind placebo-controlled clinical trial of 73 patients with asthma divided randomly in to 3 groups receiving placebo, 1 capsule of $500 \mathrm{mg}$ ground seeds of $\mathrm{N}$. sativa 2 times daily and 2 capsules of $500 \mathrm{mg}$ ground seeds of $\mathrm{N}$. sativa 2 times daily respectively, for 12 weeks along with maintenance inhaled corticosteroid therapy. The patients treated with N. sativa have shown significant improvements in forced expiratory vol- 
ume in one second (FEV1), peak expiratory flow (PEF), serum interferon- $\gamma$, and asthma control test (ACT) score and a significant reduction of fractional exhaled nitric oxide (FeNO) and serum total immunoglobulin E (IgE). Adjuvant therapy with $N$. sativa could decrease the exacerbations and improve overall control of asthma [55].

\subsection{Antihistaminic activity}

A randomized single-blind clinical trial of 20 patients with seasonal allergic rhinitis who were administered with 250 $\mathrm{mg}$ of N. sativa seeds orally for 15 days, has shown a significant reduction of seasonal allergic rhinitis symptoms score [56] and a randomized single-blind uncontrolled comparative clinical trial conducted on 47 patients with seasonal allergic rhinitis who were orally administered with either N. sativa $(250 \mathrm{mg} /$ day $)$ or montelukast $(10 \mathrm{mg} /$ day $)$ for 2 weeks, randomly. The administration of $\mathrm{N}$. sativa led to a significant reduction of daytime and ophthalmic symptoms and total eosinophil count comparable to montelukast [57]. Another randomized double blind clinical trial of $66 \mathrm{pa}-$ tients with allergic rhinitis has shown that the administration of $\mathrm{N}$. sativa oil capsules $(0.5 \mathrm{ml} /$ day $)$ for 4 weeks resulted in reduction of clinical symptoms such as nasal itching, rhinorrhea, sneezing attacks, nasal congestion, turbinate hypertrophy and mucosal pallor [58]. A total of 68 allergic rhinitis patients with different severities (mild, moderate and severe) were topically administered with 1 drop of $\mathrm{N}$. sativa seed oil in each nostril 3 times daily for 6 weeks and at the end of the study the patients with mild, moderate and severe allergic rhinitis symptoms were relieved of $100 \%$, $68.7 \%$ and $58.3 \%$ respectively [59]. It has been proposed that N. sativa may exert its antihistaminic activity through the inhibition of release of histamine and leukotrines and blocking histamine receptors [56].

\subsection{Antitussive property}

The antitussive property of N. sativa was demonstrated in guinea pigs using the aerosols of 2 different concentrations of aqueous and macerated extracts, one concentration of boiled extract, and was compared with the aerosols of codeine, and saline. After 10 minutes of exposure of aerosols of different solutions, the animals were induced with coughs by the aerosol of citric acid, and it has been noted that the number of coughs produced in animals exposed to N. sativa and codeine were significantly less compared to saline treated animals [60].

The antitussive property of thymoquinone of N. sativa was also evaluated in guinea pigs induced with coughs by the aerosol of $20 \%$ citric acid and it was compared with codeine. The intraperitoneal injections of thymoquinone and codeine reduced the number of coughs significantly. Pretreatment of animals with naloxone $(2 \mathrm{mg} / \mathrm{kg})$ abolished the antitussive effect of thymoquinone and codeine indicating that thymoquinone exerts antitussive activity by its anti-inflammatory, bronchodilatory effects mediated probably through opioid receptors [61].

\section{Conclusion}

Various randomized controlled trials, pilot studies, case reports and in vitro and in vivo studies confirmed that N.sativa has antiviral, antioxidant, anti-inflammatory, immunomodulatory, bronchodilatory, antihistaminic, antitussive activities related to causative oraganism and signs and symptoms of COVID-19. In addition, N.sativa has also shown anti-hypertensive, anti-obesity, anti-diabetic, anti-hyperlipidemic, anti-ulcer, and antineoplastic activities which would help the COVID-19 patients with comorbid conditions. Moreover, the active constituents of N. sativa such as nigellidine and $\alpha$-hederin have been identified as potential inhibitor of SARS CoV-2. N. sativa could be used as an adjuvant therapy along with repurposed conventional drugs to manage the patients with COVID-19. Adjuvant therapy of N. sativa may reduce the adverse effects of conventional medicines by helping to decrease their doses. However, more randomized controlled trials are required to confirm the potential beneficial effects of $\mathrm{N}$. sativa to treat the patients with COVID-19, as an alternative herbal medicine.

\section{Conflict of Interest}

The authors declare that there are no conflicts of interest.

\section{ORCID}

Naina Mohamed Pakkir Maideen. https://orcid.org/00000002-6950-9783.

\section{References}

1. Huang C, Wang Y, Li X, Ren L, Zhao J, Hu Y, et al. Clinical features of patients infected with 2019 novel coronavirus in Wuhan, China. Lancet. 2020;395(10223):497-506.

2. Coronavirus Outbreak. Available at: https://www.worldometers.info/coronavirus/. Accessed 21 May 2020.

3. Rodriguez-Morales AJ, Cardona-Ospina JA, Gutiérrez-Ocampo E, Villamizar-Peña R, Holguin-Rivera Y, Escalera-Antezana JP, et al. Clinical, Laboratory and Imaging Features of COVID-19: A Systematic Review and Meta-Analysis. Travel Med Infect Dis. 2020;34:101623.

4. Horowitz RI, Freeman PR, Bruzzese J. Efficacy of glutathione therapy in relieving dyspnea associated with COVID-19 pneumonia: A report of 2 cases. Respir Med Case Rep. 2020;30:101063.

5. Montero-Odasso M, Goens S, Kamkar N, Lam R, Madden K, Molnar F, et al. Canadian Geriatrics Society COVID-19 Recommendations for older adultsWhat do older adults need to know? Can Geriatr J. 2020;23(1):149-51.

6. Sanders JM, Monogue ML, Jodlowski TZ, Cutrell JB. Pharmacologic treatments for coronavirus disease 2019 (COVID-19): a review. JAMA. 2020;323(18):182436.

7. Khan MA. Thymoquinone, a constituent of prophetic medicine-black seed, is a miracle therapeutic molecule against multiple diseases. Int J Health Sci. 2019;13(1):1- 
2.

8. AlAttas SA, Fat'heya MZ, Turkistany SA. Nigella sativa and its active constituent thymoquinone in oral health. Saudi Med J. 2016;37(3):235-44.

9. Mollazadeh H, Afshari AR, Hosseinzadeh H. Review on the potential therapeutic roles of nigella sativa in the treatment of patients with cancer: Involvement of apoptosis:-black cumin and cancer. J Pharmacopuncture. 2017;20(3):158-72.

10. Kooti W, Hasanzadeh-Noohi Z, Sharafi-Ahvazi N, Asadi-Samani M, Ashtary-Larky D. Phytochemistry, pharmacology, and therapeutic uses of black seed (Nigella sativa). Chin J Nat Med. 2016;14(10):732-45.

11. Ahmad A, Husain A, Mujeeb M, Khan SA, Najmi AK, Siddique NA, et al. A review on therapeutic potential of Nigella sativa: A miracle herb. Asian Pac J Trop Biomed. 2013;3(5):337-52.

12. Khan MA, Afzal M. Chemical composition of Nigella sativa Linn: part 2 recent advances. Inflammopharmacology. 2016;24:67-79.

13. Gholamnezhad Z, Havakhah S, Boskabady MH. Preclinical and clinical effects of Nigella sativa and its constituent, thymoquinone: A review. J Ethnopharmacol. 2016;22;190:372-86.

14. Salim B, Noureddine M (2020). Identification of Compounds from Nigella Sativa as New Potential Inhibitors of 2019 Novel Coronasvirus (Covid-19): Molecular Docking Study. ChemRxiv. Preprint. https:/doi. org/10.26434/chemrxiv.12055716.v1

15. Onifade AA, Jewell AP, Onifade AB. Virologic And Immunologic Outcome of Treatment of Hiv Infectionwith a Herbal Concoction, $\alpha$-Zam, Among Clients Seeking Herbal Remedy in Nigeria. Afr J Tradit Complement Altern Med. 2011;8(1):37-44.

16. Onifade AA, Jewell AP, Ajadi TA, Rahamon SK, Ogunrin OO. Effectiveness of a herbal remedy in six HIV patients in Nigeria. Journal of herbal medicine. 2013;3(3):99103.

17. Onifade AA, Jewell AP, Adedeji WA. Nigella sativa concoction induced sustained seroreversion in HIV patient. Afr J Tradit Complement Altern Med. 2013;10(5):332-5.

18. Onifade AA, Jewell AP, Okesina AB. Seronegative conversion of an HIV positive subject treated with Nigella sativa and honey. Afr J Infect Dis. 2015;9(2):47-50.

19. Barakat EM, El Wakeel LM, Hagag RS. Effects of Nigella sativa on outcome of hepatitis C in Egypt. World J Gastroenterol. 2013;19(16):2529-36.

20. Abdel-Moneim A, Morsy BM, Mahmoud AM, Abo-Seif MA, Zanaty MI. Beneficial therapeutic effects of Nigella sativa and/or Zingiber officinale in HCV patients in Egypt. EXCLI J. 2013;12:943-55.

21. Sheir Z, Badra G, Salama O, Gomaa AI, Saber W. Effect of Combination of Some Natural Products and Chloroquine on HCV Infection in Egyptian Patients: Pilot Study. J Liver. 2013;2:1. doi:10.4172/2167-0889.1000116.

22. Salem ML, Hossain MS. Protective effect of black seed oil from Nigella sativa against murine cytomegalovirus infection. International journal of immunopharmacology. 2000;22(9):729-40.

23. Maurya S, Marimuthu P, Singh A, Rao GP, Singh G. Antiviral activity of essential oils and acetone extracts of medicinal plants against papaya ring spot virus. Journal of Essential Oil Bearing Plants. 2005;8(3):233-8.

24. Oyero OG, Toyama M, Mitsuhiro N, Onifade AA, Hidaka A, Okamoto M, et al. Selective inhibition of hepatitis c virus replication by Alpha-zam, a Nigella sativa seed formulation. Afr J Tradit Complement Altern Med. 2016;13(6):144-8.

25. Umar S, Munir MT, Subhan S, Azam T, Nisa Q, Khan MI, et al. Protective and antiviral activities of Nigella sativa against avian influenza (H9N2) in turkeys. J Saudi Soc agric Sci; 2016.

26. Khan AU, Tipu MY, Shafee M, Khan NU, Tariq MM, Kiani MR, et al. In-ovo antiviral effect of Nigella sativa extract against Newcastle Disease Virus in experimentally infected chicken embryonated eggs. Pak Vet J. 2018;38(4):434-7.

27. Aqil K, Khan MU, Aslam A, Javeed A, Qayyum R, Yousaf F, et al. In vitro Antiviral Activity of Nigella sativa against Peste des Petits Ruminants (PPR) Virus. Pakistan JZool. 2018;50(6):2223-8.

28. Delgado-Roche L, Mesta F. Oxidative Stress as Key Player in Severe Acute Respiratory Syndrome Coronavirus (SARS-CoV) infection. Arch Med Res. 2020; S0188-4409(20)30540-3.

29. Wang JZ, Zhang RY, Bai J. An anti-oxidative therapy for ameliorating cardiac injuries of critically ill COVID-19-infected patients. Int J Cardiol. 2020;312:137-8.

30. Namazi N, Mahdavi R, Alizadeh M, Farajnia S. Oxidative stress responses to Nigella sativa oil concurrent with a low-calorie diet in obese women: A randomized, double-blind controlled clinical trial. Phytother Res. 2015;29(11):1722-8.

31. Kaatabi H, Bamosa AO, Badar A, Al-Elq A, Abou-Hozaifa B, Lebda F, et al. Nigella sativa improves glycemic control and ameliorates oxidative stress in patients with type 2 diabetes mellitus: placebo controlled participant blinded clinical trial. PloS one. 2015;10(2).

32. Mostafa RM, Moustafa YM, Mirghani Z, AlKusayer GM, Moustafa KM. Antioxidant effect of garlic (Allium sativum) and black seeds (Nigella sativa) in healthy postmenopausal women. SAGE Open Med. 2013;1:2050312113517501.

33. Bordoni L, Fedeli D, Nasuti C, Maggi F, Papa F, Wabitsch $\mathrm{M}$, et al. Antioxidant and anti-inflammatory properties of Nigella sativa oil in human pre-adipocytes. Antioxidants. 2019;8(2):51.

34. Hu X, Liang Y, Zhao B, Wang Y. Thymoquinone protects human retinal pigment epithelial cells against hydrogen peroxide induced oxidative stress and apoptosis. J Cell Biochem. 2019;120(3):4514-22.

35. Burits M, Bucar F. Antioxidant activity of Nigella sativa essential oil. Phytother Res. 2000;14(5):323-8.

36. Chen L, Deng H, Cui H, Fang J, Zuo Z, Deng J, et al. Inflammatory responses and inflammation-associated diseases in organs. Oncotarget. 2018;9(6):7204.

37. Merad M, Martin JC. Pathological inflammation in patients with COVID-19: a key role for monocytes and macrophages. Nat Rev Immunol. 2020;20(6):355-362.

38. Stebbing J, Phelan A, Griffin I, Tucker C, Oechsle O, Smith D, et al. COVID-19: combining antiviral and anti-inflammatory treatments. Lancet Infect Dis. 
2020;20(4):400-2.

39. Gheita TA, Kenawy SA. Effectiveness of Nigella sativa oil in the management of rheumatoid arthritis patients: a placebo controlled study. Phytother Res. 2012;26(8):1246-8.

40. Hadi V, Kheirouri S, Alizadeh M, Khabbazi A, Hosseini H. Effects of Nigella sativa oil extract on inflammatory cytokine response and oxidative stress status in patients with rheumatoid arthritis: a randomized, double-blind, placebo-controlled clinical trial. Avicenna J Phytomed. 2016;6(1):34-43.

41. Mahdavi R, Namazi N, Alizadeh M, Farajnia S. Nigella sativa oil with a calorie-restricted diet can improve biomarkers of systemic inflammation in obese women: A randomized double-blind, placebo-controlled clinical trial. J Clin Lipidol. 2016;10(5):1203-11.

42. Hadi S, Mirmiran P, Daryabeygi-Khotbesara R, Hadi V. Effect of Nigella sativa oil extract on inflammatory cytokine response and oxidative stress among people with type 2 diabetes mellitus: a randomized, double-blind, placebo controlled trial. Progress in Nutrition. 2018;20(1-S):127-33.

43. Amizadeh S, Rashtchizadeh N, Khabbazi A, Ghorbanihaghjo A, Ebrahimi AA, Vatankhah AM,et al. Effect of Nigella sativa oil extracts on inflammatory and oxidative stress markers in Behcet's disease: A randomized, double-blind, placebo-controlled clinical trial. Avicenna J Phytomed. 2020;10(2):181.

44. Mansour M, Tornhamre S. Inhibition of 5-lipoxygenase and leukotriene $\mathrm{C} 4$ synthase in human blood cells by thymoquinone. J Enzyme Inhib Med Chem. 2004;19(5):431-6.

45. Ingraham NE, Lotfi-Emran S, Thielen BK, Techar $\mathrm{K}$, Morris RS, Holtan SG, et al. Immunomodulation in COVID-19. Lancet Respir Med. 2020;S22132600(20)30226-5.

46. Salem ML. Immunomodulatory and therapeutic properties of the Nigella sativa L. seed. Int immunopharmacol. 2005;5(13-14):1749-70.

47 Işık H, Çevikbaş A, Gürer ÜS, Kıran B, Üresin Y, Rayaman $P$, et al. Potential adjuvant effects of Nigella sativa seeds to improve specific immunotherapy in allergic rhinitis patients. Med Princ Pract. 2010;19(3):206-11.

48. Kheirouri S, Hadi V, Alizadeh M. Immunomodulatory effect of Nigella sativa oil on T lymphocytes in patients with rheumatoid arthritis. Immunol Invest. 2016;45(4):271-83.

49. Fogarty H, Townsend L, Ni Cheallaigh C, Bergin C, Martin-Loeches I, Browne P, et al. More on COVID-19 Coagulopathy in Caucasian patients. Br J Haematol. 2020;12:11.1111.

50. Jose RJ, Manuel A. COVID-19 cytokine storm: the interplay between inflammation and coagulation. Lancet Respir Med. 2020;S2213-2600(20)30216-2.

51. Lebda FM, Bamosa AO, Kaatabi H, Al Elq A, Al-Sultan A. Effect of Nigella sativa on hemodynamics, hemoglobin, and blood coagulation in patients with type 2 diabetes. The Egyptian Journal of Haematology. 2012;37(2):73.

52. Muralidharan-Chari V, Kim J, Abuawad A, Naeem M, Cui H, Mousa SA. Thymoquinone modulates blood coagulation in vitro via its effects on inflammatory and coagulation pathways. Int J Mol Sci. 2016;17(4):474.

53. Yusof AN. Screening of Haemostatic Activity of Nigella Sativa Seed Extract. Journal of Engineering and Health Sciences. 2017;1(1):57-74.

54. Boskabady MH, Mohsenpoor N, Takaloo L. Antiasthmatic effect of Nigella sativa in airways of asthmatic patients. Phytomedicine. 2010;17(10):707-13.

55. Salem AM, Bamosa AO, Qutub HO, Gupta RK, Badar A, Elnour A, et al. Effect of Nigella sativa supplementation on lung function and inflammatory mediators in partly controlled asthma: a randomized controlled trial. Ann Saudi Med. 2017;37(1):64-71.

56. Ansari MA, Ahmed SP, Haider SA, Ansari NL. Nigella sativa: A non-conventional herbal option for the management of seasonal allergic rhinitis. Pak J Pharm. 2006;23(2):31-5.

57. Ansari MA, Ansari NA, Junejo SA. MONTELUKAST VERSUS NIGELLA SATIVA FOR MANAGEMENT OF SEASONAL ALLERGIC RHINITIS: A SINGLE BLIND COMPARATIVE CLINICAL TRIAL. Pakistan Journal of Medical Sciences. 2010;26(2).

58. Nikakhlagh S, Rahim F, Aryani FH, Syahpoush A, Brougerdnya MG, Saki N. Herbal treatment of allergic rhinitis: the use of Nigella sativa. Am J Otolaryngol. 2011;32(5):402-7.

59. Mohamed Alsamarai A, Abdulsatar M, Hamed Ahmed Alobaidi A. Evaluation of topical black seed oil in the treatment of allergic rhinitis. Antiinflamm Antiallergy Agents Med Chem. 2014;13(1):75-82.

60. Boskabady MH, Kiani S, Jandaghi P, Ziaei T, Zarei A. Antitussive effect of Nigella sativa in guinea pigs. Pakistan Journal of Medical Sciences. 2004;20:224-8.

61. Hosseinzadeh H, Eskandari M, Ziaee T. Antitussive effect of thymoquinone, a constituent of Nigella sativa seeds, in guinea pigs. Pharmacologyonline. 2008;2:4804. 